\title{
Decentralization and the duration of fiscal consolidation: shifting the burden across layers of government
}

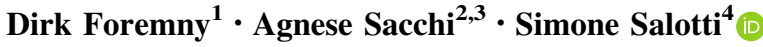

Received: 23 May 2016/Accepted: 2 March 2017/Published online: 16 March 2017

(C) The Author(s) 2017. This article is an open access publication

\begin{abstract}
This paper analyzes the relationship between fiscal decentralization, the duration of fiscal consolidation episodes, and their success for 17 OECD countries between 1978 and 2009. The consolidation of the general government budget appears to be of longer duration when expenditure decisions are more decentralized. We also find that transfers from higher levels of government are cut during consolidation episodes, suggesting that central governments shift the burden of consolidation towards lower tiers of government. This is especially true when the latter have little legal autonomy to raise tax revenues and have little influence over executive decisions taken at the central level. We document that this increases local governments' public debt/GDP ratios. In terms of the success of consolidation episodes, countries with greater degrees of decentralization appear to make smaller improvements in their primary balance when consolidating.
\end{abstract}

Keywords Fiscal consolidation · Duration analysis · Fiscal decentralization

JEL Classification E62 $\cdot \mathrm{H} 60 \cdot \mathrm{H} 77$

Disclaimer: The views expressed are purely those of the authors and may not in any circumstances be regarded asstating an official position of the European Commission.

Simone Salotti

Simone.SALOTTI@ec.europa.eu

Dirk Foremny

foremny@ub.edu

Agnese Sacchi

agnese.sacchi@uniroma1.it

1 Institut d'Economia de Barcelona (IEB), University of Barcelona, Barcelona, Spain

2 La Sapienza University of Rome, Rome, Italy

3 La Sapienza University of GEN, Vigo, Spain

4 European Commission, Joint Research Centre (JRC), Directorate B - Growth and Innovation, Circular Economy and Industrial Leadership Unit, Edificio Expo, C/Inca Garcilaso, 3, 41092 Seville, Spain 


\section{Introduction}

In the wake of the recent financial and economic crisis and during the ensuing recession, many OECD countries have opted to consolidate their general government budget balances. To achieve this goal, many have implemented severe austerity packages, with highly controversial results (Blyth 2013). General questions related to fiscal consolidation, including political economy considerations and macroeconomic conditions, have been studied extensively in the literature (Price 2010; Mauro 2011; Grüner 2013). Yet, despite the fact that many central governments recently have delegated substantial powers to subnational entities (Rodríguez-Pose and Ezcurra 2011), the question as to whether fiscal decentralization strengthens governments' ability to implement fiscal adjustment measures remains unanswered. ${ }^{1}$

A key question concerning fiscal consolidation is its duration, a factor that is closely related to its effectiveness (see, e.g., Bi et al. 2013). ${ }^{2}$ This appears to have been confirmed in the on-going debate as to which factors help sustain a consolidation effort. The point at stake seems to be the following: what is the optimal speed of fiscal consolidation and for how long should it be implemented? In other words, should governments concentrate their efforts at the beginning of the process and subsequently relax policy measures, or should they adopt the reverse approach? Blanchard and Leigh (2013) claim that these decisions depend on country-specific factors including, but not limited to, the level of public debt, economic growth, and interest rates. For example, austerity measures implemented in times of low or negative growth may damage the economy rather than help it recover (Ostry et al. 2016) and, in such cases, better strategies than upfront fiscal consolidation may be available.

The arguments for concentrating consolidation efforts at the beginning of the process have to be seen in the light of the default risks perceived by financial markets and of the costs of servicing public debt, since immediate fiscal adjustment measures might increase a government's credibility and reassure market participants. ${ }^{3}$ This hypothesis is confirmed by Briotti (2004), who identifies persistent fiscal adjustment efforts as the best way to enhance credibility and ensure success as measured in terms of impact on deficits, debt, and growth performances. More recently, Barrios et al. (2010) have argued that sharp, sustained consolidations are more likely to be successful in countries with high starting debt levels and high interest rates (or low GDP growth potential), but that more gradual adjustments are preferable when these constraints are more relaxed.

However, despite the obvious importance of determining the optimum duration of a fiscal consolidation, no clear consensus has yet been reached. Thus, the hypothesis that decentralization can play a role in this process-in terms of how, to what extent, and with what results-is an appealing research question. A recent IMF policy paper (2014) recognizes the importance of intergovernmental fiscal coordination for the development of an effective consolidation plan. Indeed, institutional arrangements for coordinating financial decision-making between levels of government appear to be an increasingly important

\footnotetext{
1 A previous version of this paper was presented at the OECD Fiscal Federalism Network Workshop in Paris and some of the results were published in the conference volume (Foremny et al. 2014).

2 According to Bi et al. (2013), the duration of fiscal consolidation-beyond its nature and compositionmatters in terms of determining the extent to which a given consolidation is expansionary and/or successful in stabilizing government debt.

3 This was the case of Ireland in 2010, when the government decided to frontload a 4-year, 15 billion euro deficit correction sooner rather than later.
} 
factor in the success of a government's adjustment strategies. ${ }^{4}$ However, the fiscal objectives of most advanced economies tend to cover the general government sector only, and recognize no clearly identifiable contribution of sub-national levels of government to the targeted budget balance and debt position. Additionally, the distribution of the adjustment burden across the various layers of government is not pre-determined, and so it remains dependent on the strength of intergovernmental fiscal arrangements. An examination of the recent experiences of advanced countries seems to show that sub-national governments deliver proportionally larger shares of the overall reduction in the general government deficit than is delivered by the central government (Blöchliger 2013; Vammalle and Hulbert 2013). Our research explores this point in greater depth by analyzing the relationship between fiscal consolidation and decentralization. Should decentralization prove to be related to the duration of the former, this would have significant policy implications with different ramifications for federal and centralized countries.

From a theoretical viewpoint, fiscal decentralization may either favor or impede the governmental consolidation efforts. On the one hand, in a more decentralized system, the number of veto players increases, impeding the adoption of corrective packages and potentially deteriorating into a typical common-pool problem. Indeed, in times of crisis, a combination of deficit bias and coordination failures owing to fiscal decentralization may result in over-spending (and/or under-taxation) tendencies at the sub-national level as well as the adoption of conflicting fiscal stances at central and sub-central levels (see, e.g., Jonas 2012; Eyraud and Moreno Badia 2013; Foremny and von Hagen 2012).

Central governments, on the other hand, may consolidate their balances by simply cutting their inter-governmental transfers to sub-national units. In this way, they avoid having to face the direct political costs of such unpopular measures. The more expenditure is in the hands of sub-central tiers of government without corresponding revenue powers (as tends to be the case in most decentralized and advanced economies; see Blöchliger and Vammalle 2012), the more the burden can be shifted to sub-national levels. However, in these circumstances, the reactions of local governments to the negative revenue shock are crucial. If the reduction in transfers simply translates into an increase in sub-national deficits, no consolidation will have been achieved from a general government perspective. Today, various cooperative arrangements (including internal stability pacts and sub-national fiscal rules) have been put in place between central and sub-national governments (as exemplified by Austria, Germany and Italy), making sub-national constraints more binding and fiscal adjustment targets easier to achieve.

All of those possibilities depend heavily on the financing structure of the different levels of government: just how much autonomy do local governments really have over their own budgets? Foremny and von Hagen (2013) suggest that the actual degree of sub-central autonomy and reliance on transfers can have a critical impact on the relationship between decentralization and consolidation efforts. The authors report that sub-national governments in unitary countries experienced a significant increase in transfers from central government during the Great Recession, something that did not occur in the federal states. This suggests that the composition of transfers and changes in their configuration during periods of consolidation may depend on the degree of fiscal decentralization, and on the true assignment of powers to different tiers of government. In close relation to this, the

\footnotetext{
${ }^{4}$ Neyapti $(2010,2013)$ puts forward the idea that decentralization could be considered to be an appropriate institutional mechanism able to sustain fiscal adjustment and to promote fiscal discipline over time. Escolano et al. (2012) claim that the latter is particularly true when sub-central governments have the power to raise adequate resources and revenues to cover their expenditures.
} 
presence of sub-national fiscal rules that limit certain budgetary items may also influence the duration and intensity of adjustment episodes. However, evidence of the disciplinary effects of sub-national rules (Nannicini et al. 2016; Escolano et al. 2012; Foremny 2014; Reuter 2015) has not yet been able to disentangle the discipline effect from the possibility of simultaneous bailouts from upper levels of government.

Our aim here, therefore, is to combine the literature on fiscal consolidation with that on fiscal federalism and decentralization. The specific question we address is whether more decentralized countries consolidate their budgets for longer periods than is the case with more centralized countries. We then examine the possible mechanisms behind our findings. More specifically, we study how central government transfers change during periods of consolidation as a means of determining whether such transfers are used by central governments to achieve their consolidation objectives. Finally, we analyze how countries with different systems of decentralization achieve their consolidation objectives in terms of the impact on public budget deficits and public debt, that is, we examine the relationship between fiscal decentralization and the success of the consolidation effort. ${ }^{5}$

Our main finding can be stated as follows: periods of fiscal consolidation are of longer duration in countries in which larger proportions of public spending are in the hands of sub-central tiers of government. This is especially true when such governments do not enjoy any real autonomy over their revenues. We also document a reduction in intergovernmental transfers during episodes of fiscal consolidation, suggesting that central governments shift the burden of consolidation onto lower levels of government whenever possible, at the expense of prolonging the consolidation process. Finally, we show that consolidation is, on average, less capable of improving the budget balance/GDP ratio in more decentralized countries, but at the same time is less damaging in terms of its impact on the public debt/GDP ratio in these countries. Our findings have interesting implications given the widespread concerns regarding the fiscal imbalances that currently characterize most developed economies.

The rest of the paper is organized as follows. Section 2 offers a brief literature review of fiscal consolidation, focusing on such aspects as its duration, determinants and success. Section 3 illustrates the empirical strategy we adopt to investigate our research question. Section 4 contains the results of the analysis, and Sect. 5 concludes.

\section{Related literature}

Studies of fiscal consolidation have focused their attention on such issues as the factors that lead to the adoption of consolidation efforts, the determinants of their success, and the duration of the episodes. Existing empirical studies focus primarily on OECD countries, while interest in the subject has been revived by the recent economic and financial crisis and the calls heard for fiscal adjustments in most industrialized countries.

\footnotetext{
5 The main drawback of such an analysis is that the term "success" in this context can be defined in many ways. Thus, the effects of a period of consolidation might be perceived positively or negatively depending on the means adopted to achieve fiscal sustainability. For example, according to one strand in the literature (e.g., Alesina and Perotti 1995; Alesina and Ardagna 2010), a fiscal consolidation is deemed successful if the reduction in the debt-to-GDP ratio (or the primary budget-balance-to-GDP ratio) is sufficiently large and persistent. In contrast, another strand (e.g., Lodge and Rodriguez-Vives 2013) defines "success" in terms of the persistence (length or longevity) of the fiscal consolidation effort over time. In the analyses undertaken here, we take into account both aspects of the success of a fiscal consolidation episode.
} 
First, it should be stressed that no single definition of what constitutes a successful consolidation effort exists. For instance, Von Hagen and Strauch (2001) measure success in terms of the reduction in the budget deficit achieved at the end of the adjustment period. Alesina and Ardagna (2010) define a consolidation effort as having been successful when the cyclically adjusted primary balance (CAPB) as a share of GDP improves by $1.5 \%$ points or more. Barrios et al. (2010) distinguish between "cold shower" improvements of $1.5 \%$ points in the CAPB that are recorded in the space of one year and "gradual consolidations" that take place over 3 years if in each year the CAPB does not deteriorate by more than $0.5 \%$ of GDP.

An alternative definition considers a consolidation effort successful if the reduction in gross public debt achieved at the end of the episode has made the latter either sustainable or substantially smaller than it was at the outset (Heylen and Everaert 2000), although the debt/GDP ratio usually increases following a consolidation effort (Ardagna 2009) because of the adverse effects on the denominator of this ratio. ${ }^{6}$ Additionally, it might be claimed that the success of a fiscal adjustment program is related to the persistence of the consolidation effort: that is, for how long can (and should) a government consolidate its budgetary balances?

Changes in the expenditure/revenue mix would seem to play a key role in determining the outcome of a consolidation effort, although no consensus has emerged on the exact nature of those changes. On the one hand, spending-based adjustments are more likely to be successful, as they appear to be linked to longer lasting reductions in deficit/GDP ratios (e.g., Alesina and Perotti 1995; Afonso et al. 2006; Barrios et al. 2010; Alesina and Ardagna 2012). Devries et al. (2011) also claim that spending-based adjustments have been less contractionary in the past, but only because of accommodative monetary policy. At the same time, relying on higher taxes to reduce deficits may damage potential growth by discouraging labor market participation, and by lowering investment and firm profitability owing to the distortionary impact of taxes (especially those on income).

On the other hand, revenue-based consolidations may be more effective in terms of fiscal adjustments, particularly if they involve the revenues that are potentially less harmful for growth, that is, user fees, environmental taxes, property taxes and value-added taxes (Heylen and Everaert 2000; Tsibouris et al. 2006). In fact, revenue-based consolidations have been implemented in the past and several scholars recognize their effectiveness, especially when initial revenue-to-GDP ratios are relatively low. Moreover, it appears that the ex post composition of adjustments often turns out to be different from those originally planned, with expenditure cuts falling short of target and over-performing revenue changes (Tsibouris et al. 2006; Mauro 2011; Mauro and Villafuerte 2013).

In addition to changes in the expenditure/revenue mix, initial conditions also seem to matter in determining the success of fiscal consolidation efforts. In their seminal contribution, Von Hagen and Strauch (2001) investigate when fiscal adjustments are likely to be initiated, and under what circumstances consolidation efforts are likely to be successful, for a sample of European countries during the 1990s. The cyclical positions of the domestic and the international economy, the initial debt level, and the fiscal policy stance are all shown to be important determinants of the likelihood of a fiscal consolidation, as well as of its success. Barrios et al. (2010) also report that countries facing larger initial levels of government debt have a higher probability of pursuing successful fiscal consolidations. Cafiso and Cellini (2014) stress that although a certain debt/GDP ratio may affect the

${ }^{6}$ Debt sustainability is not readily defined. Neck and Sturm $(2008$, p. 1) claim that "although sustainability of public finance has been discussed for more than a century now, it is still an imprecise concept". 
likelihood of consolidation, the opposite also is true, as consolidation affects debt dynamics. Their analysis of EU countries for the 1980-2009 period suggests that consolidation leads to lower debt/GDP values in the short-run, but not in the medium term.

On the other hand, Alesina and Ardagna (2012) find that initial conditions make no difference to the success or otherwise of a consolidation episode, while Devries et al. (2011) show that the role played by initial conditions is at best unclear. Molnar (2012) analyzes the economic environment, political settings and policy measures conducive to fiscal consolidation and debt stabilization and finds that the existence of fiscal rules and cooperation between different tiers of government play a critical role in favor of fiscal adjustment programs. The political framework also is relevant as newly elected governments seem more likely to initiate and sustain fiscal consolidation episodes, while noncentrist political parties are less likely to make efforts to stabilize debt than are those closer to the center of the political spectrum.

Another important dimension of a consolidation episode is its duration, an element that usually has been studied using survival analysis techniques. According to a European Commission study (2007), gradual consolidations tend to be more successful than quick, sharp adjustments, although the latter may be more effective in the case of high and rising debt levels. Below we summarize findings in relation to the duration of past fiscal adjustment efforts.

Von Hagen et al. (2002) were the first to concentrate on the duration of fiscal consolidation episodes and to make the length of the consolidation efforts endogenous in the empirical analysis. Their influential results highlight the importance of consolidation fatigue and of fiscal conditions such as public debt over GDP in determining the duration of fiscal consolidation. Illera and Mulas-Granados (2008) study the factors affecting the length of fiscal consolidation episodes, defined as the time spells between two fiscal expansions (which are in turn defined on the basis of the dynamics of the CAPB) in 15 European countries between 1960 and 2004. They find that the probability of a period of fiscal consolidation coming to an end, what the authors refer to as 'failure' (the term being taken from the standard survival analysis tools, where hazard functions are used to estimate the probability of a certain event, normally labelled as the 'failure rate'), depends on such factors as the debt level, the magnitude of the adjustment, the relative contribution of spending cuts, and the degree of cabinet fragmentation.

It is worth noting that defining consolidation episodes solely on the basis of cyclically adjusted budget balance improvements may constitute too narrow an approach, since not all periods in which the balance did not improve should be considered failures (e.g., governments may simply not want to consolidate). In this respect, the data and definition provided by the IMF (Devries et al. 2011) seem to be more appropriate for investigating the duration of consolidation efforts. Here, fiscal consolidation episodes are classified using a narrative/historical approach based on the analysis of the policymakers' intentions and actions as described in contemporary policy documents. Thus, the tax and spending measures taken in such periods are motivated primarily by the desire to reduce the budget deficit and not by a response to prospective economic conditions. We employ this type of data in our empirical analysis and so avoid the potential bias attributable to measurement errors that potentially correlate with economic developments and omit those consolidation efforts that are followed by adverse shocks that offset the discretionary measures. A further consequence of using this definition of consolidation is that its success is not 'embedded' in the definition, as the episodes in our dataset do not depend on numerical changes in the public deficit. 
A more recent contribution to the study of the duration of consolidations is provided by Lodge and Rodriguez-Vives (2013), who estimate hazard functions for 20 advanced economies between 1970 and 2010. According to their analysis, the fiscal and macroeconomic conditions at the outset appear to affect the ability of governments to sustain lengthy consolidations. More precisely, high debt and deficits, heavy interest burdens, and high government bond yields all facilitate the initiation of consolidation (the so-called 'push factors'); while, large private savings, strong external balances, competitiveness (measured by real exchange rate), and stable financial conditions facilitate its duration (the 'pull factors'). Lodge and Rodriguez-Vives (2013) find that the composition of the fiscal adjustment (i.e., the split between expenditure and revenue measures) does not appear to be a significant determinant of the duration of consolidation.

Agnello et al. (2013), on the other hand, when using annual data for 17 industrial countries over the 1978-2009 period, find a difference between spending- and tax-driven consolidations, with the former episodes being shorter than the latter. Moreover, both types of consolidation are longer in non-European countries than they are in European countries, while the size of the consolidation program (in percentage of GDP) is not correlated significantly with its duration. ${ }^{7}$

As pointed out recently by the OECD (Vammalle and Hulbert 2013), successful national consolidation strategies usually benefit from involving sub-national governments. Moreover, to be successful, they also need to take into account the financial situation of these sub-national tiers so as to maintain the local authorities' capacity to deliver major public services. Failure to do so can lead to breakdowns in coordination between different tiers of government, with adverse consequences for fiscal adjustment actions. Although it is acknowledged widely that sub-national governments are key players in fiscal policymaking, few studies of the durations of consolidations have paid close attention to their role or examined fiscal decentralization and intergovernmental fiscal relations.

Limited empirical evidence is available on this question. In the case of emerging market economies, Thornton and Adedeji (2010) find that sub-national governments have, in the past, contributed to successful general government fiscal adjustments by cutting their capital expenditures and raising their own tax revenues. In contrast, Baldacci et al. (2006) find no robust effects of fiscal decentralization (measured with simple dummies indicating the authority states and provinces have over fiscal policy) on the success of fiscal consolidation in a panel of 25 emerging market economies [note that they build on previous research on emerging economies by Adam and Bevan (2003) and Gupta et al. (2005)].

In the case of developed countries, Schaltegger and Feld (2009), in a case study of the Swiss cantons, find that fiscal centralization significantly reduces the probability of a successful fiscal consolidation, suggesting that competitive fiscal federalism may positively impact fiscal discipline. Darby et al.'s (2005) study of fiscal consolidations in OECD countries lends further support to the idea of the constructive participation of sub-national governments, with fiscal consolidations occurring at both central and sub-national levels. While other articles have investigated the role of fiscal federalism in the context of fiscal consolidation, they have not focused their attention on its relationship to the duration of the episode. It is this gap that we attempt to fill here with our original empirical research.

\footnotetext{
7 Studies of the duration of fiscal adjustment episodes also have been undertaken for a sample of developing countries where, using survival analysis, expenditure composition, the size of the fiscal consolidation, and past fiscal consolidation performance are identified as factors that affect the persistence of the adjustment (Gupta et al. 2004).
} 


\section{Empirical approach}

\subsection{Data}

The data used in this paper are collected from various sources. First, data on consolidation episodes are provided by the IMF and are based on an analytical examination of budget policy documents, budget speeches, reports submitted to national banks and supranational organizations, which seek to identify governmental intentions to initiate a period of consolidation (Devries et al. 2011 outline the historical approach followed in gathering the data and offer a detailed explanation). In the dataset, the consolidation dummy takes the value 1 in those years in which the government expressed the willingness to consolidate its budget balances. Relevant documents identify policy actions that are motivated by attempts to reduce the deficit, certifying the resoluteness of policy-makers at the beginning of a fiscal consolidation program (i.e., when decisions were taken), as well as of the budgetary impact of these measures during and at the end of the adjustment.

This approach limits our sample to 17 OECD countries $^{8}$ for the 1978-2009 period, but it provides us with a more reliable approach than if we were to identify consolidation episodes solely on the basis of changes in the cyclically adjusted primary balance. For example, the latter method may lead us to consider instances in which the budget balance improved owing to circumstances other than that of the government's wish to consolidate its finances. Likewise, cyclically adjusted series may suffer from measurement errors that are likely to correlate with other economic developments (for similar applications, see Agnello et al. 2013). Moreover, if our definition of consolidation is based on improvements in the cyclically adjusted primary balance, any evaluation of success might suffer from a sample selection problem and an overestimation of the success of the consolidation episodes.

Second, we augment the dataset with information about fiscal decentralization, edec, measured in terms of the proportion of expenditure in the hands of sub-central governments divided by the general government's expenditure (source: OECD). This is the standard approach to measuring the degree of fiscal decentralization, although it does tend to overstate the actual degree of sub-national governmental autonomy, given that some types of expenditure are labelled 'local' even though sub-central governments have little power over them and they can be mandated by the central government or spent on its behalf (Ebel and Yilmaz 2003). ${ }^{9}$

For this reason, we also include measures accounting for real sub-national autonomy. These additional variables address matters of fiscal independence, the influence of subnational sectors, and the co-determination of policy making between sub-national and central levels of government. This information is provided by the Regional Authority Indices developed by Hooghe et al. (2010). Fiscal autonomy (fiscal autonomy) is a measure of the extent to which a regional government independently can tax its population. The minimum value (0) applies when the central government fixes all regional tax bases and rates, while the maximum (5) applies when the regional government has the right to define the tax base and rate of at least one major tax. Executive influence (executive influence) is

\footnotetext{
8 The countries included in our sample are Australia, Austria, Belgium, Canada, Denmark, Finland, France, Germany, Ireland, Italy, Japan, the Netherlands, Portugal, Spain, Sweden, the United Kingdom and the United States.

9 Alternative measures of fiscal decentralization have been constructed (most notably, see Stegarescu 2005), but their use would impose a severe loss of observations owing to missing data.
} 
defined as the extent to which a regional government can affect and co-determine national policy at intergovernmental meetings and ranges between 0 and 2. Finally, the indicator of co-determination (shared ruling) increases if a regional government can exercise authority by co-determining decisions at the national level either by direct participation in the design of national laws, by sharing executive responsibilities with the national government, or by having an influence on the distribution of tax revenues in the country as a whole. This third indicator varies between 0 and 12 and also takes into account whether the regional government can exercise any authority over the country's constitutional set-up.

All of the other variables employed in the analysis have been selected from the few studies conducted to date analyzing the durations of fiscal consolidations (Von Hagen et al. 2002; Illera and Mulas-Granados 2008; Molnar 2012; Agnello et al. 2013); however, the literature has not reached a consensus yet on which controls should be included in the type of analysis performed here. The controls in our model are defined as follows: (a) debt and $\operatorname{debt}(t-1)$, the contemporaneous and the 1-year lagged values of gross public debt divided by GDP, respectively, taken from the IMF Historical Debt database compiled by Mauro et al. (2013); (b) primary balance $(t-1)$, the lagged general government primary balance over GDP (source: OECD), which, together with (a), accounts for the initial fiscal conditions that might affect the duration of the consolidation episodes; (c) real gdp growth, the growth rate of real GDP per capita (source: Penn World Tables) to capture the macroeconomic conditions likely to be influencing the durations of consolidations; (d) election year, a dummy carrying information about national election years; (e) government type, a categorical variable distinguishing among single-party and coalition governments ${ }^{10}$; (f) right wing, a dummy taking the value of 1 for right-wing governments and zero otherwise (source: the Comparative Political Dataset compiled by Armingeon et al. 2012). Note that variables (d) to (f) are included to control for the political factors affecting consolidation. Finally, the effects of monetary policy are proxied by the following: (g) $\Delta$ interest rate, the change in the nominal long-term interest rate on government bonds (source: OECD) and (h) $\Delta$ interest payments, the change in the interest paid on public debt divided by GDP (source: IMF; Mauro et al. 2013). Finally, the type of fiscal consolidation can also influence duration and is represented by (h) tax-based consolidation, a dummy taking the value of 1 when consolidation is focused on the revenue side of the budget. Table 1 reports the summary statistics for the variables in our analysis.

Figure 1 presents the Kaplan-Meier survival function for the fiscal consolidation duration data. The lengths of the horizontal sections of the line on the $\mathrm{x}$-axis represent the survival duration for that interval, which is determined by the end of the consolidation episode. For example, the probability of a consolidation episode lasting at least one year is $100 \%$, which basically reflects the annual frequency of the data and the fact that at least one consolidation episode with a duration of only one year is observed (in total, 13 such episodes occur in our sample). The probability declines as the length of the consolidation episode increases, reaching zero for periods longer than 14 years (the reason for this being that, in our sample, only one 14-year long episode is observed-Canada between 1984 and 1997 - and no episodes last longer than that). The vertical distances between the horizontal sections of the line illustrate the change in cumulative probability of the consolidation episode ending as time elapses. The most notable 'jumps' are associated with the consolidation episodes that last just a few years, and which are the most numerous in our

10 The variable takes the following values: (1) for single-party majority governments, (2) for minimal winning coalitions, (3) for surplus coalitions, (4) for single-party minority governments, (5) for multi-party minority governments, and (6) for caretaker governments. 
Table 1 Summary statistics

\begin{tabular}{|c|c|c|c|c|c|}
\hline Variables & $\mathrm{N}$ & Mean & SD & Min & $\operatorname{Max}$ \\
\hline consolidation & 527 & 0.315 & 0.465 & 0.000 & 1.000 \\
\hline edec & 544 & 36.588 & 14.008 & 8.661 & 65.605 \\
\hline fiscal autonomy & 498 & 2.088 & 1.514 & 0.000 & 4.800 \\
\hline executive influence & 498 & 0.528 & 0.747 & 0.000 & 2.000 \\
\hline shared ruling & 498 & 3.061 & 3.352 & 0.000 & 12.000 \\
\hline debt & 544 & 57.184 & 25.844 & 4.288 & 134.065 \\
\hline primary balance $(t-1)$ & 527 & -0.086 & 3.195 & -10.377 & 9.011 \\
\hline real gdp growth & 544 & 2.487 & 2.375 & -8.354 & 11.495 \\
\hline election year & 544 & 0.305 & 0.461 & 0.000 & 1.000 \\
\hline government type & 544 & 2.447 & 1.303 & 1.000 & 6.000 \\
\hline right wing & 544 & 0.557 & 0.497 & 0.000 & 1.000 \\
\hline interest rate & 527 & 0.117 & 1.847 & -15.268 & 9.211 \\
\hline interest payments & 527 & 0.004 & 0.512 & -2.226 & 2.286 \\
\hline $\log ($ transfers $)$ & 345 & 10.529 & 1.295 & 7.149 & 13.164 \\
\hline
\end{tabular}

Source See text, and authors' calculations

Fig. 1 Kaplan-Meier survival function

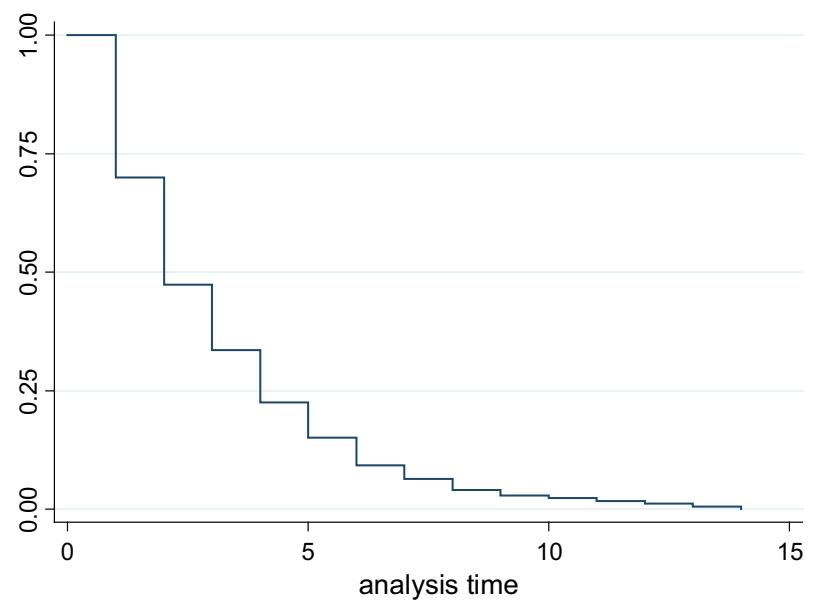

sample (for example, we observe 15 two-year episodes in the sample, but only 5 six-years episodes).

\subsection{Identification}

Our empirical approach comprises three separate steps. First, we perform a duration analysis in order to estimate the determinants of the lengths of fiscal consolidations. The advantage of such an analysis is that it exploits all information available in the data, enabling the treatment of the duration of fiscal consolidation as endogenous (Gupta et al. 2004). In this way, we are able to study how long governments managed to sustain 
uninterrupted periods of consolidation in the past and what factors affected their ability to do so. However, a number of caveats should be borne in mind, namely, that a duration analysis does not deal, among other things, with the economic and welfare consequences of consolidation, and it does not directly provide information about debt sustainability or the success of fiscal consolidation in achieving a lasting reduction in government debt ratios (Lodge and Rodriguez-Vives 2013). More importantly for our purposes, we wish to gain a full understanding of the impact of fiscal decentralization and sub-central autonomy on the duration of fiscal consolidation episodes. To do so, we initially estimate the determinants of the time $h$ taken by a country to consolidate with a standard duration model such as the following:

$$
h(t, Z)=h_{0}(t) \times(\mathbf{Z} \gamma+\mathbf{X} \beta)
$$

In (1), the baseline hazard $h_{0}$ follows the Weibull model as this is the most flexible specification of the ones commonly employed in the literature. In this case, the following holds: $h_{0}(t)=p \times t^{(\rho-1)}$. The parameter $\rho$ as the baseline hazard is estimated as an endogenous part of the model. Vector $\mathbf{Z}$ includes the variables measuring decentralization and sub-central autonomy, which constitute the main focus of our analysis. Matrix $\mathbf{X}$ is a set of control variables. All variables vary over time throughout the respective consolidation episode. In the case of $\mathbf{Z}$, we are interested in whether-and how-consolidation at the general level of government is affected by the degree of fiscal decentralization and by the sub-national institutional setting. Therefore, in the baseline model, we investigate the effect of expenditure decentralization and include only the variable edec in $\mathbf{Z}$ (in fact, for purposes of comparison and robustness, we also report the estimates arising from a parsimonious specification that excludes vector $\mathbf{Z}$ entirely and which conforms more closely to analyses in the existing literature).

Subsequently, we estimate three alternative specifications of model (1), obtained by augmenting $\mathbf{Z}$ separately with each of the indicator variables that account for real subnational autonomy (fiscal autonomy, executive influence, and shared ruling) and their respective interaction terms with expenditure decentralization (edec). We focus on one indicator per specification to avoid potential issues of multicollinearity, as the three variables all seek to capture a similar dimension, i.e., real sub-central autonomy, and are likely to be correlated with one another. The control variables included in vector $\mathbf{X}$ are as listed in Sect. 3.1.

The second step in our study involves an analysis of the impact of a consolidation period on sub-national public finances. Our aim here is not to provide causal interpretations, but rather to present correlation-based evidence on whether or not fiscal consolidation has affected intergovernmental transfers to sub-national sectors. To do so, we estimate the following equation:

$$
\Delta \log \left(\text { transfers }_{i, t}\right)=\beta \times \text { consolidation }_{i, t} \times \Omega+\eta_{i}+\varepsilon_{i, t},
$$

where $\Omega$ is equal to one of the three variables included in the interactions in the previous step. The dependent variable is the change in the intergovernmental transfers received by sub-national governments from the central government, for which descriptive statistics are reported in Table 1. To analyze the effect, we compute the marginal effects of the consolidation episodes, conditional on the values of the interacted variable between the consolidation dummy and the real sub-central autonomy index (each introduced separately). 
The third and last step in our analysis involves examining the relationship between decentralization and the success of a government's consolidation efforts, regarding which the literature provides scant evidence. A notable exception here is Schaltegger and Feld (2009), who suggest that more decentralized countries tend to be more successful in their consolidation strategies, although this result is based solely on data for the Swiss cantons. We use both descriptive statistics and simple econometrics to examine the relationship between decentralization and the numerical results achieved by the various consolidation episodes in our sample in terms of their effects on both the budget balance/GDP and the public debt/GDP ratios. This allows us to gain additional insights into the role of decentralization in government-led consolidation processes.

\section{Results}

\subsection{The duration analysis}

Table 2 presents the estimates of Eq. (1) above. The first specification (reported in the first column of Table 2) includes only the control variables taken from the existing literature (vector $\mathbf{X}$ ) and does not include the decentralization variable, which facilitates comparisons of our results with those published in earlier analyses. The estimates in the second and third columns include expenditure decentralization $(e d e c)$, which is, in fact, our main variable of interest. $^{11}$

The negative and significant effect of edec (see both columns 2 and 3 in Table 2) indicates that more decentralized countries have a lower hazard rate, i.e., that the probability of a consolidation period lasting for an additional year increases with higher degrees of decentralization. Figure 2 illustrates this survival function for different levels of decentralization. The survival function for countries with a $50 \%$ degree of decentralization (the line farthest to the right) is significantly shifted to the right compared to countries with lower degrees of decentralization. Therefore, ceteris paribus, more decentralized countries consolidate for longer periods.

The rest of the independent variables in the model return the expected signs, but many are not statistically significant. On the macroeconomic side, it emerges that an increase in interest payments makes it more likely that a consolidation period will be terminated sooner. On the political side, we find that right-wing governments tend to consolidate for longer periods, ceteris paribus. While the political cycle does not appear to affect the duration of the consolidation episodes (the coefficient associated with the election year dummy is not statistically significant), the coefficient for type of government shows a significant and negative impact. Another interesting result is that consolidations based on tax hikes are more likely to result in shorter consolidation episodes.

Thus, our initial analysis suggests that fiscal decentralization has a significant effect on the duration of fiscal consolidation. We seek now to identify the channel responsible for

\footnotetext{
11 Column 3 in Table 2 contains the estimates of the model using a different definition of expenditure decentralization. In this specification, the decentralization ratio is held constant over time at its average value for a given country. This additional regression seeks to address the potential endogeneity between fiscal consolidation and decentralization. It addresses the fact that as central government expenditure is reduced (as a result of consolidation efforts), the decentralization ratio mechanically increases (as the denominator declines). The fact that our results are robust across columns 2 and 3 (Table 2) ensures that the parameter identified on edec is not driven by this mechanical relationship occurring in the time-series dimension of our data (i.e., the time variability of edec is neglected in the estimate reported in column 3 ).
} 
Table 2 Baseline results of the duration analysis

Survival time estimation assuming the Weibull survival distribution. Robust standard errors in parentheses

$* * * p<0.01$; ** $p<0.05$; $* p<0.10$

Fig. 2 Survival function: survival probability and decentralization
Survival time

(1)

(2)

(3)

Decentralization

edec

$$
\begin{array}{ll}
-0.030 * * * & -0.032 \text { *** } \\
(0.008) & (0.008)
\end{array}
$$

\begin{tabular}{|c|c|c|c|}
\hline primary balance $(t-1)$ & $\begin{array}{l}-0.067 * \\
(0.036)\end{array}$ & $\begin{array}{l}-0.056 \\
(0.036)\end{array}$ & $\begin{array}{l}-0.071 * * \\
(0.035)\end{array}$ \\
\hline $\operatorname{debt}(t-1)$ & $\begin{array}{l}0.020 \\
(0.028)\end{array}$ & $\begin{array}{l}0.006 \\
(0.029)\end{array}$ & $\begin{array}{l}0.005 \\
(0.029)\end{array}$ \\
\hline debt & $\begin{array}{l}-0.040 \\
(0.028)\end{array}$ & $\begin{array}{l}-0.025 \\
(0.028)\end{array}$ & $\begin{array}{l}-0.025 \\
(0.028)\end{array}$ \\
\hline$\Delta$ interest payments & $\begin{array}{l}0.498 * * * \\
(0.167)\end{array}$ & $\begin{array}{l}0.497 * * * \\
(0.165)\end{array}$ & $\begin{array}{l}0.493 * * * \\
(0.171)\end{array}$ \\
\hline real gdp growth & $\begin{array}{l}-0.188 * * * \\
(0.055)\end{array}$ & $\begin{array}{l}-0.139 * * \\
(0.057)\end{array}$ & $\begin{array}{l}-0.142 * * \\
(0.056)\end{array}$ \\
\hline$\Delta$ interest rate & $\begin{array}{l}0.036 \\
(0.051)\end{array}$ & $\begin{array}{l}0.000 \\
(0.052)\end{array}$ & $\begin{array}{l}-0.002 \\
(0.052)\end{array}$ \\
\hline election year & $\begin{array}{l}0.107 \\
(0.163)\end{array}$ & $\begin{array}{l}0.119 \\
(0.165)\end{array}$ & $\begin{array}{l}0.110 \\
(0.167)\end{array}$ \\
\hline right wing & $\begin{array}{l}-0.548 * * * \\
(0.169)\end{array}$ & $\begin{array}{l}-0.273 \\
(0.183)\end{array}$ & $\begin{array}{l}-0.271 \\
(0.181)\end{array}$ \\
\hline government type & $\begin{array}{l}-0.703 * * * \\
(0.169)\end{array}$ & $\begin{array}{l}-0.406^{* *} \\
(0.190)\end{array}$ & $\begin{array}{l}-0.406^{* *} \\
(0.185)\end{array}$ \\
\hline tax based consolidation & $\begin{array}{l}0.248 * \\
(0.131)\end{array}$ & $\begin{array}{l}0.209 * * \\
(0.088)\end{array}$ & $\begin{array}{l}0.201 * * \\
(0.082)\end{array}$ \\
\hline \multicolumn{4}{|l|}{ Hazard parameters } \\
\hline Constant & $\begin{array}{l}-0.156 \\
(0.245)\end{array}$ & $\begin{array}{l}0.407 \\
(0.283)\end{array}$ & $\begin{array}{l}0.476^{*} \\
(0.283)\end{array}$ \\
\hline $\ln (\rho)$ & $\begin{array}{l}0.667 * * * \\
(0.051)\end{array}$ & $\begin{array}{l}0.712 * * * \\
(0.052)\end{array}$ & $\begin{array}{l}0.715 * * * \\
(0.052)\end{array}$ \\
\hline Number of observations & 166 & 166 & 166 \\
\hline
\end{tabular}

Controls

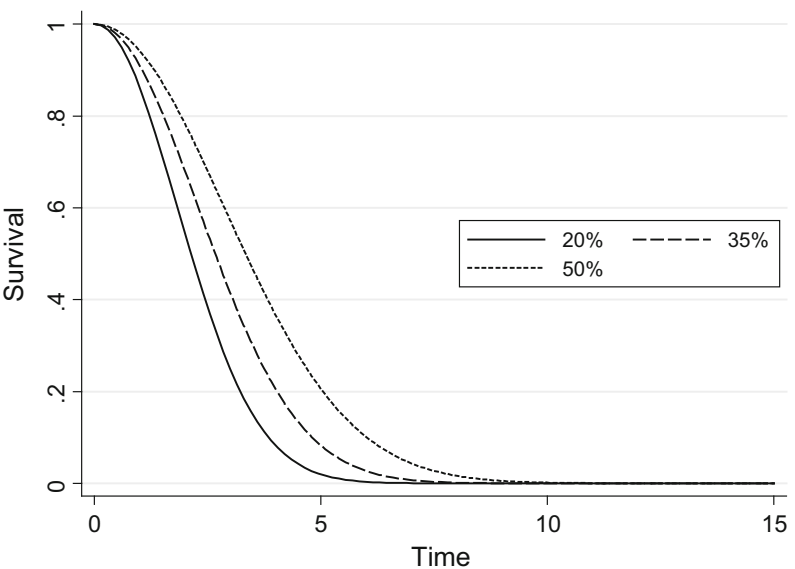


this effect. On the one hand, more decentralized countries may find it easier to consolidate for longer periods simply because central governments can shift the adjustment burden down to sub-national sectors. On the other hand, the positive impact on duration could be explained by the fact that sub-national governments contribute substantially to the stabilization function of economies making it easier to sustain longer lasting consolidation efforts. The first effect would be more pronounced if fewer legal powers have been transferred to sub-national sectors: if sub-central governments are responsible for large shares of expenditure, but do not possess corresponding revenue-raising powers, it is easy for the central government to cut transfers to the detriment of lower governmental layers. We test this hypothesis by augmenting the model with the respective indicators of real autonomy and their interaction terms with decentralization. The results are presented in Table 3 .

In general, the negative coefficient on expenditure decentralization holds across all specifications. However, the baseline effect is significant only when the indicator for executive influence is entered in the model, which might indicate a problem of collinearity, given that in some instances expenditure decentralization might evolve in line with the real autonomy variables. Including an interaction term in model (1) between expenditure decentralization and a real autonomy indicator (any one of the three included separately in the model) results in a positive and statistically significant coefficient associated with the main effect of fiscal autonomy and a negative coefficient on the interaction term. This implies that decentralized countries consolidate for longer periods but that the fiscal autonomy of sub-national governmental tiers can dampen this to the point that the result is offset if sub-national governments have enough real autonomy over their fiscal policies. To interpret the negative interaction term and to illustrate the overall effect, we plot the survival functions in Figs. 3, 4 and 5 for different combinations of the two variables, introducing the three real autonomy variables separately.

In Fig. 3, the line furthest to the left represents the effect obtained with a high degree of fiscal autonomy at sub-national levels and a low degree of expenditure decentralization ( $20 \%$ of the sample). Countries with these characteristics tend to consolidate for shorter periods of time. With the same level of expenditure decentralization, but with no fiscal autonomy, the consolidation spells have, on average, a slightly longer duration as the survival curve shifts to the right. This indicates that, in countries that have quite a high degree of centralization, greater real fiscal autonomy might avoid the adjustment burden being shifted to sub-national sectors (whether this indeed happens is analyzed in the next step after discussing the other effects of real autonomy on duration). Turning to the countries characterized by high degrees of decentralization (around $50 \%$ of the sample), the curves shift as expected to the right, as greater decentralization increases survival probability, that is, the probability of having longer consolidation spells. In fact, these two survival functions furthest to the right almost overlap. With no fiscal autonomy, the main effect of decentralization is found to prevail, as the interaction term and the main effect of fiscal autonomy both are equal to zero When switching to a high autonomy regime, we would expect a shift to the left, as such regimes were found to consolidate for shorter periods of time. However, this effect is largely offset by the negative interaction term, which acquires considerable relative importance. ${ }^{12}$ At this level of decentralization, it seems that switching from a high- to low-fiscal autonomy model of decentralization no longer affects the duration of the consolidation episodes.

12 This occurs even for the maximum value of fiscal autonomy (which is equal to 2) when keeping edec around $50 \%$. 
Table 3 Duration analysis with interaction effects
Survival time estimation assuming the Weibull survival distribution. Robust standard errors in parentheses.

$* * * p<0.01$; ** $p<0.05$;

$* p<0.10$. All models replicate Model (3) of Table 2 but include the respective interaction terms. Model (1) with fiscal autonomy, Model (2) with executive influence, and Model (3) with fiscal rules
Survival time

(1)

(2)

(3)

Decentralization

edec

$$
-0.013
$$

(0.018)

$-0.022 * *$

$-0.023$

Autonomy

fiscal autonomy

$0.508 * *$

(0.241)

executive influence

$2.571 * * *$

(0.822)

shared ruling

$0.142 *$

(0.078)

Interaction terms

$$
\begin{aligned}
& \text { fiscal autonomy } \cdot \text { edec } \\
& \text { executive influence } \cdot \text { edec } \\
& \text { shared ruling } \cdot \text { edec }
\end{aligned}
$$

$-0.011^{*}$

(0.006)

$-0.056^{* * * *}$

(0.019)

$-0.031$

(0.031)

Controls

primary balance $(t-1)$
debt $(t-1)$
debt

$-0.077 * *$
$(0.036)$
0.023

$-0.151^{* * * *}$

$-0.078^{* *}$

(0.039)

(0.038)

(0.032)

0.033

0.015

$-0.041$

(0.033)

(0.033)

(0.031)

$-0.052$

$-0.035$

$0.553 * * *$

(0.032)

(0.032)

$\triangle$ interest payments

(0.173)

$0.497 * * *$

$0.447 * *$

real gdp growth

$-0.145^{* *}$

(0.153)

(0.180)

(0.063)

$-0.145^{* *}$

$-0.146^{* *}$

$-0.016$

(0.064)

(0.065)

$\Delta$ interest rate

(0.054)

$-0.042$

(0.049)

$-0.012$

0.109

0.155

(0.169)

(0.159)

(0.055)

election year

$-0.110$

(0.209)

$-0.111$

(0.196)

0.088

(0.172)

right wing

government type

tax based consolidation

$-0.379 *$

(0.196)

Hazard parameters

\begin{tabular}{llll} 
Constant & -0.652 & -0.520 & 0.069 \\
& $(0.691)$ & $(0.425)$ & $(0.381)$ \\
$\ln (\rho)$ & $0.718 * * *$ & $0.751^{* * *}$ & $0.711^{* * *}$ \\
& $(0.051)$ & $(0.058)$ & $(0.051)$ \\
Number of observations & 162 & 162 & 162 \\
\hline
\end{tabular}

$-0.276$

(0.219)

0.035

(0.213)

$0.204 * *$

$0.194 * *$

(0.089)

(0.091)

$-0.297$

(0.205)

$0.221 * *$

(0.095)

The results for real executive influence, illustrated in Fig. 4, are in line with those obtained for fiscal autonomy. This finding suggests that decentralization does not operate solely through the interaction term, but it also shifts the survival function to the right by 


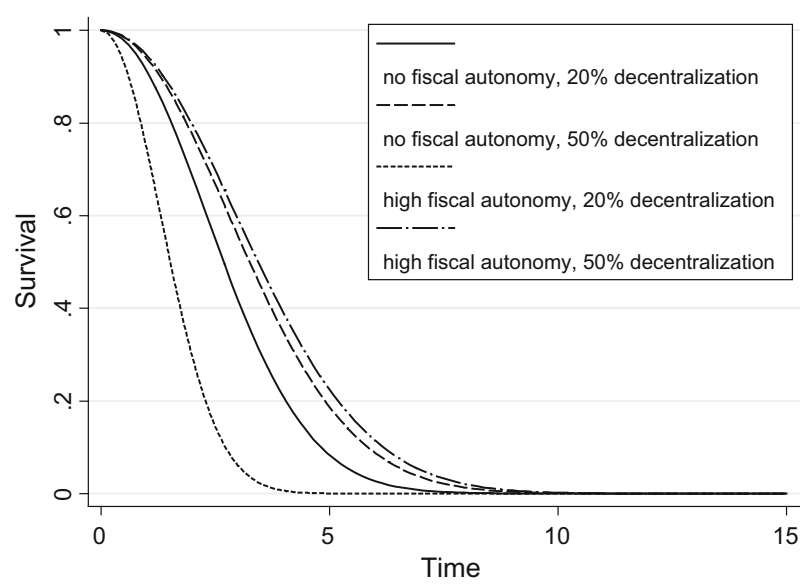

Fig. 3 Survival function: impact of decentralization and fiscal autonomy

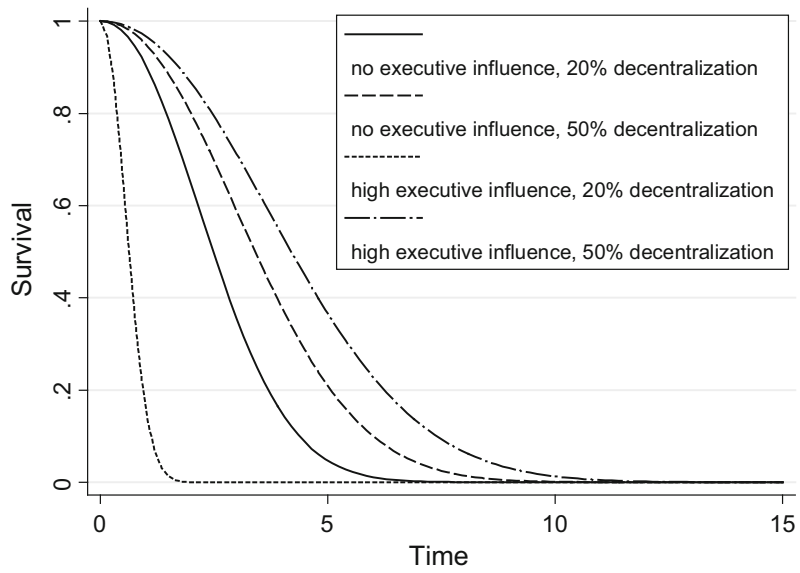

Fig. 4 Survival function: impact of decentralization and executive influence

itself. While the order of the lines is the same as in Fig. 3, the impact of decentralization now more than offsets the reduction in the survival probability owing to executive influence. Figure 5 completes the analysis by showing the results for the indicator for the codetermination of national decision-making (shared ruling). Again, the results are similar to those obtained for the other two indicators, suggesting that the most important component in the institutional arrangements is the fiscal element and highlighting the importance of the proper design of the fiscal institutions shaping intergovernmental relations.

Thus, the results so far suggest that countries with high degrees of decentralization tend to consolidate for longer periods; however, this effect is mitigated by greater real autonomy in the hands of sub-central governments. In contrast, if countries are decentralized to a lesser degree (here 20\%), central governments can shift the burden of longer consolidation periods to those lower tiers of government, unless, that is, they are shielded by some element of real autonomy. If sub-national governments possess a sufficiently high degree of real autonomy, the duration of consolidation periods tends not to be so long. However, 


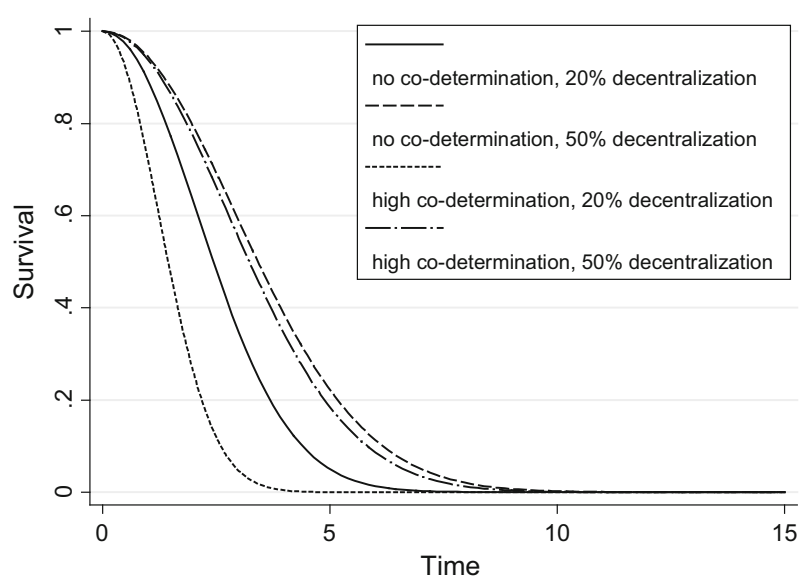

Fig. 5 Survival function: impact of decentralization and shared ruling

with a high degree of decentralization with respect to expenditure, real sub-national autonomy essentially makes little difference.

\subsection{The effects on sub-national public finances}

The second step in the analysis, the estimation of Eq. (2), seeks to determine whether the fact that more decentralized economies consolidate for longer periods is driven by cuts in transfers to sub-national tiers of government. Table 4 suggests that implementing consolidation measures and the duration of such measures (consolidation and consolidation time, respectively) both affect the change in intergovernmental transfers negatively. In other words, when statistically significant, the effect of consolidation periods on subnational public finances is negative. This suggests that fiscal consolidation in the past has reduced the intergovernmental transfers received by local governments. In addition, the negative baseline effect of consolidation is even larger in magnitude when controlling for real sub-central autonomy (mainly fiscal autonomy and executive influence, as observed in columns 2, 3 and 5).

An examination of the effect of real sub-central autonomy seems to show that only shared ruling significantly and positively affects the change in intergovernmental transfers (columns 4 and 8). This means that if a regional government or its representatives can exercise authority over the institutional set-up by co-determining national legislation and policy through intergovernmental conferences (e.g., by either directly participating in making national law or by sharing executive responsibilities with the national government for implementing policy either in the region or in the country as a whole), ${ }^{13}$ central government transfers may increase. This finding suggests that the more regions are able to write the rules of the game, the more they are likely to obtain in terms of resources from a bargaining process with the central authority.

\footnotetext{
${ }^{13}$ An example is provided by Italy's State-Regions Conference, at which the central government, the regions and the autonomous provinces of Trento and Bolzano promote intergovernmental cooperation. This conference is the arena for the political negotiations between the central government and the regional authorities. All aspects of supranational European policy of regional and provincial interest also are discussed in this framework.
} 


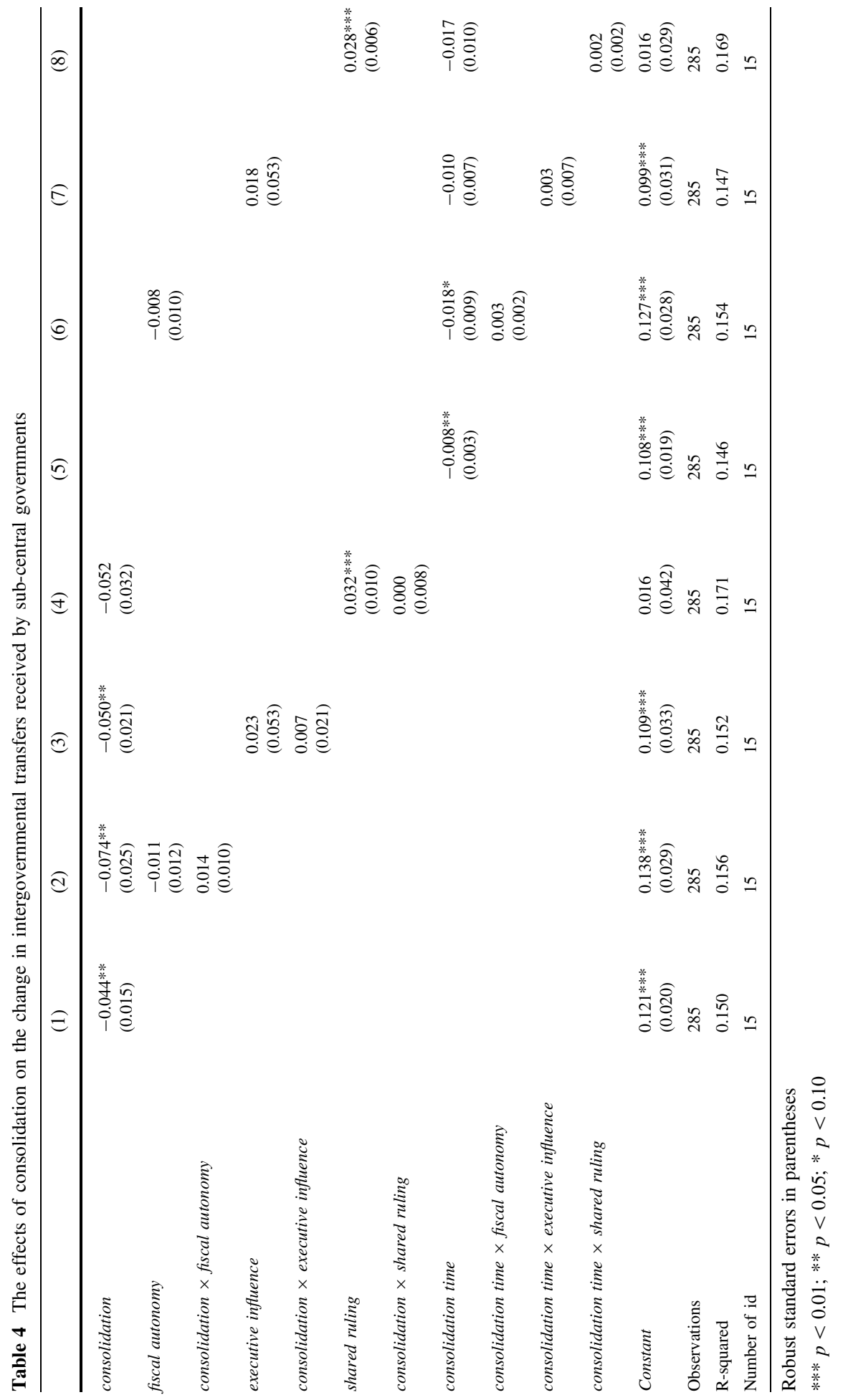


In order to analyze the joint effect of consolidation and real local autonomy on the change in transfers, it therefore seems worth considering the interaction between the two. In this respect, Fig. 6 plots the marginal effect of a consolidation period on the logdifference of transfers for all the possible values of the fiscal autonomy variable.

The slope of the interaction terms proves not to be significant in the regression. Nevertheless, the figure provides a number of interesting insights. First, during consolidation periods, transfers to lower levels of government are substantially reduced as the impact of consolidation is negative and different from zero. This suggests that consolidation-at least partially-has been achieved in the past by reducing transfers to sub-national levels, confirming the stylized facts presented in Vammalle and Hulbert (2013). However, the effect is different from zero only as long as real autonomy, measured here in terms of fiscal autonomy, is not sufficiently large. Sub-national sectors with a high degree of fiscal autonomy can use this additional power to prevent central government cuts in their transfer revenue.

Similar evidence is offered when repeating the exercise with the other two indicators of real sub-central autonomy, that is, executive influence and shared ruling (Figs. 7, 8).

While the slope becomes flatter, the estimated averages remain negative, indicating transfer cuts during consolidation periods. Here again, sub-national sectors that enjoy substantial influence in policy making do not experience any significant reductions in transfers during consolidation periods, given that for higher values of this indicator, consolidation periods are not characterized by any significant cuts in transfers to lower levels of government.

\subsection{The success of consolidation}

The last step in our analysis examines the success of the consolidation episodes in terms of the reduction achieved in the public debt/GDP ratio and the improvement attained in the budget balance/GDP ratio. This step builds on previous studies that have adopted similar empirical strategies for identifying successful fiscal consolidations (e.g., Alesina and Perotti 1995; Heylen and Everaert 2000; Alesina and Ardagna 2010). ${ }^{14}$ Table 5 shows the average changes in the budget balance/GDP and public debt/GDP ratios during the consolidation episodes in our sample. Statistics are presented for the full sample as well as for the two sub-samples of countries grouped by their degree of decentralization, i.e., considering expenditure decentralization below and above its average.

On average, the primary balance/GDP ratio improves during periods of consolidation, with annual values between +0.44 and $+2.01 \%$ points of GDP. Long consolidation episodes achieve substantial cumulative increases in this ratio, with a maximum of +16.11 , which is the average total change for the 2 eight-year periods in the sample. In most cases, the average yearly improvement in the primary balance/GDP ratio is greater for less decentralized countries (i.e., with values of expenditure decentralization below the edec mean), particularly for very short consolidation episodes. For example, in the nine one-year consolidations in countries with low degrees of decentralization, the primary balance/GDP ratio improved by an average of $1.54 \%$ points, while in more decentralized countries it increased by just $0.55 \%$ points of GDP. A further finding, which is unsurprising given the

\footnotetext{
${ }^{14}$ It should be noted that since the consolidation episodes in our dataset are identified through a narrative approach, such episodes do not necessarily entail specific changes in variables, such the ratio of public deficit over GDP or of CAPB/GDP. However, it is customary to label as successful those consolidation efforts thanks to which such ratios are increased.
} 


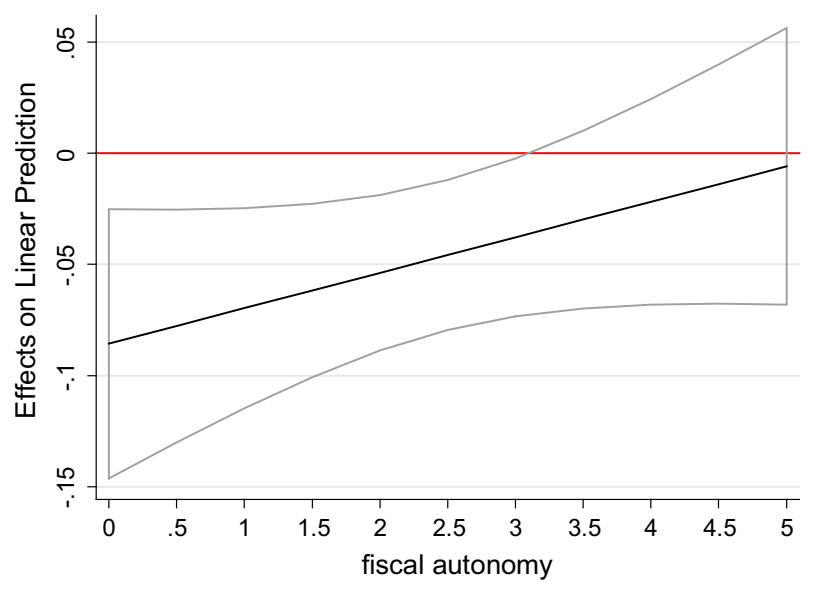

Fig. 6 Consolidation burden on transfers: impact of fiscal autonomy

results of our analysis above, is that the majority of the short-lived episodes of consolidation are concentrated in the sub-sample of countries with low levels of expenditure decentralization.

Table 5 also reports the impact on the public debt/GDP ratio, where the total change is calculated as the value of debt/GDP at the end of the consolidation period minus its value in the year immediately preceding the start of the consolidation episode. On average, the debt/GDP ratio increases when governments reduce the primary deficit, something that can only be explained in terms of the adverse effects on GDP of the consolidation efforts and high interest payments in these periods. In fact, Perotti (2012) convincingly argues that the four cases normally presented as proof that austerity measures can be expansionary should be considered exceptions rather than the rule. In our sample, the debt/GDP ratio increases on average during consolidation episodes, in many cases quite notably (for instance, the average increase for the three five-year episodes is equal to +21.32). Interestingly, when episodes of the same length appear in both sub-samples, the highest average increases in the debt-to-GDP are concentrated in the sub-sample of the less decentralized countries (the one exception being the debt increase during the two-year long consolidation episodes).

Thus, our evidence shows not only that consolidation episodes are of longer duration when expenditure decentralization is higher, but it also seems to indicate that improvements in the primary balance/GDP ratio are, on average, less pronounced. Our results are in line with those reported by Darby et al. (2005), who use a smaller unbalanced panel of 15 OECD countries for the 1970-1999 period, ${ }^{15}$ and find that high levels of expenditure decentralization may result in a fiscal environment that is not conducive to successful consolidation attempts.

While the previous exercise was carried out for the general government, the following (and final) analysis of the success of consolidation seeks to disentangle the consequences of consolidation for central and local public finances, respectively. We estimate simple econometric models with the change in the central and local government debt/GDP ratios (introduced separately) as dependent variables, and with the variables characterizing the

15 Darby et al.'s fiscal consolidation measures are defined as discretionary attempts to improve general government fiscal balances. 


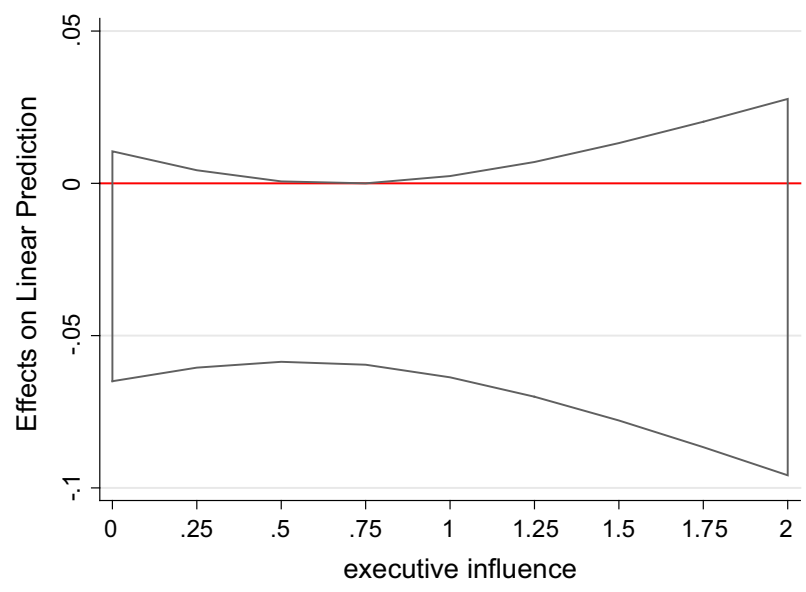

Fig. 7 Consolidation burden on transfers: impact of executive influence

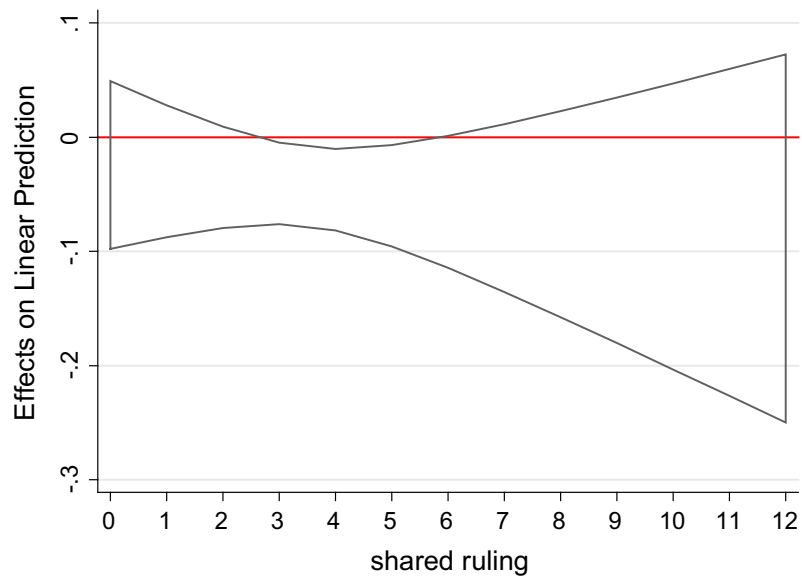

Fig. 8 Consolidation burden on transfers: impact of shared ruling

consolidation episodes on the right-hand side. The results are reported in Table 6 and they show a positive correlation between both consolidation events (i.e. consolidation) and their duration (i.e. consolidation time) with increases in the central governments' debt/GDP ratios, although the estimated coefficients are not statistically significant (see columns 1 and 6). In the case of the change in sub-national debt, the correlation with consolidation is positive while that with duration is negative, but once again the coefficients are not statistically significantly different from zero (see columns 2 and 7).

However, some statistically significant evidence of consolidation emerges when controlling for the level of real sub-national autonomy (see columns 4 and 5). Indeed, the coefficient on fiscal consolidation is positive and becomes significant, suggesting that the change in sub-national debt-to-GDP ratio increases when consolidation packages are implemented at the country level. This "shift" effect from central to local government public finances during consolidation seems in fact to be mitigated by the real authority exerted by sub-national governments, as demonstrated by the negative (and significant) 
Table 5 Average changes in deficit/GDP and debt/GDP during consolidation episodes

\begin{tabular}{|c|c|c|c|c|}
\hline \multirow{2}{*}{$\begin{array}{l}\text { Episodes' length (no. of episodes } \\
\text { in parenthesis) }\end{array}$} & \multicolumn{2}{|c|}{ Change in primary balance/GDP } & \multicolumn{2}{|c|}{ Change in debt/GDP } \\
\hline & Yearly & Total & Yearly & Total \\
\hline \multicolumn{5}{|l|}{ Full sample } \\
\hline $1(13)$ & 1.24 & 1.24 & 2.81 & 2.81 \\
\hline $2(15)$ & 0.72 & 1.44 & 1.38 & 2.77 \\
\hline $3(5)$ & 0.91 & 2.72 & 2.17 & 6.52 \\
\hline $4(6)$ & 0.99 & 3.98 & 2.15 & 8.61 \\
\hline $5(3)$ & 0.52 & 2.61 & 4.26 & 21.32 \\
\hline $6(5)$ & 1.12 & 6.75 & 2.12 & 12.70 \\
\hline $7(1)$ & 1.44 & 10.05 & 3.57 & 24.97 \\
\hline $8(2)$ & 2.01 & 16.11 & 3.16 & 25.31 \\
\hline $9(1)$ & 0.44 & 3.92 & 0.26 & 2.36 \\
\hline $14(1)$ & 0.57 & 7.93 & 2.71 & 37.92 \\
\hline \multicolumn{5}{|c|}{ Expenditure decentralization below average } \\
\hline $1(9)$ & 1.54 & 1.54 & 3.62 & 3.62 \\
\hline $2(10)$ & 0.83 & 1.66 & 0.58 & 1.15 \\
\hline $3(4)$ & 0.95 & 2.84 & 2.28 & 6.84 \\
\hline $4(3)$ & 1.08 & 4.31 & 2.30 & 9.19 \\
\hline $6(2)$ & 0.77 & 4.63 & 2.64 & 15.84 \\
\hline $7(1)$ & 1.44 & 10.05 & 3.57 & 24.97 \\
\hline $8(2)$ & 2.01 & 16.11 & 3.16 & 25.31 \\
\hline \multicolumn{5}{|c|}{ Expenditure decentralization above average } \\
\hline $1(4)$ & 0.55 & 0.55 & 0.98 & 0.98 \\
\hline $2(5)$ & 0.50 & 1.01 & 3.01 & 6.01 \\
\hline $3(1)$ & 0.74 & 2.23 & 1.74 & 5.23 \\
\hline $4(3)$ & 0.91 & 3.65 & 2.01 & 8.02 \\
\hline $5(3)$ & 0.52 & 2.61 & 4.26 & 21.32 \\
\hline $6(3)$ & 1.36 & 8.16 & 1.77 & 10.61 \\
\hline $9(1)$ & 0.44 & 3.92 & 0.26 & 2.36 \\
\hline $14(1)$ & 0.57 & 7.93 & 2.71 & 37.92 \\
\hline
\end{tabular}

Source Devries et al. (2011) and authors' calculations. The countries with below average expenditure decentralization are: Austria, Belgium, France, Ireland, Italy, the Netherlands, Portugal, Spain, and the United Kingdom. The countries with above average expenditure decentralization are: Australia, Canada, Denmark, Finland, Germany, Japan, Sweden, and the United States

coefficients on the interaction terms. Hence, in countries with enough real sub-national autonomy, the increase in the variation of the debt/GDP ratio is smaller during a consolidation episode. This confirms the hypothesis that sub-national governments with sufficient political power and influence in politics at the center are shielded against this type of intervention, and is in line with the results reported by Foremny and von Hagen (2013), who find a similar effect for federal versus unitary countries.

Similar results hold in the case of consolidation time as shown in column 9, where the interaction between consolidation time and executive influence is negative and statistically significant, while the coefficient on consolidation time alone is positive. Ultimately, consolidation efforts at the national level can worsen local public sectors' fiscal stances- 


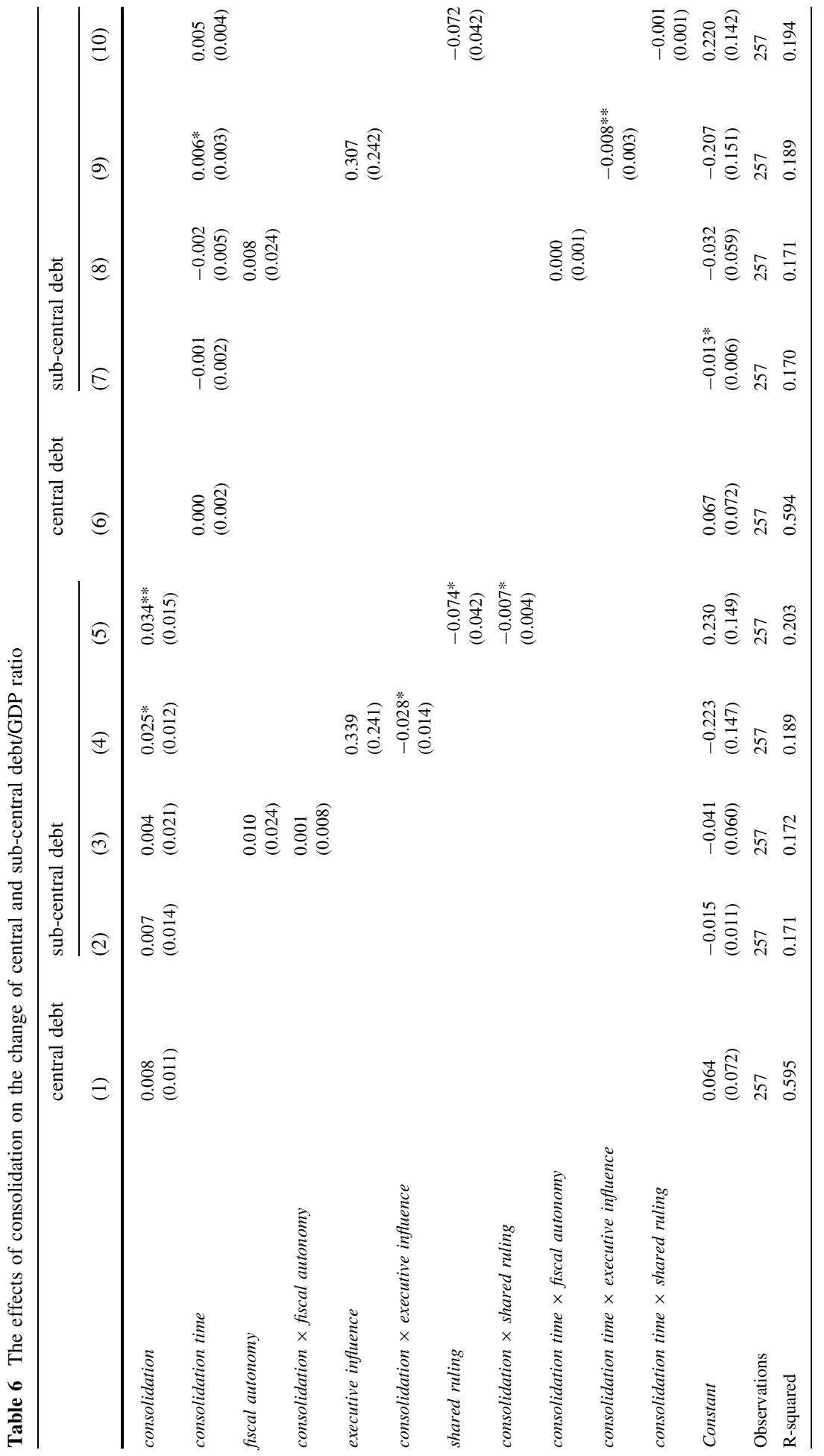




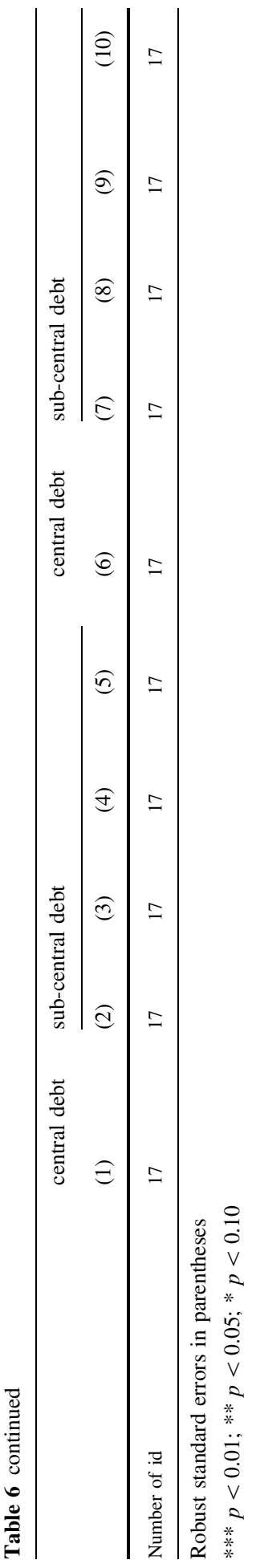


i.e., increasing their change in debt-to-GDP ratios-if the latter do not have sufficient authority, responsibility and participation with respect to the central government and its fiscal decisions.

\section{Conclusion}

The need to adjust public finances and address government fiscal imbalances has generated a heated debate as to which fiscal tools (e.g., spending review measures, changes in tax systems) should be used and how they should be employed to restore sustainable fiscal positions. Research conducted to date has concerned itself primarily with analyzing the welfare and economic effects of the austerity measures implemented and with identifying the determinants of successful fiscal adjustment plans.

An important issue that has gone largely unexplored in these studies is the duration of these fiscal consolidation processes; yet, identifying the elements that might affect it constitutes an interesting research question. The IMF has suggested that fiscal institutions may be appropriate tools to sustain fiscal adjustment measures over time (Blanchard and Cottarelli 2010). Among such institutions, the organization of intergovernmental fiscal relations between the tiers of political authorities appears to be a natural candidate for influencing the length of a consolidation process. On the one hand, coordination failures and deficit bias problems may arise in the presence of multiple government tiers and agencies; however, on the other hand, more efficient and effective fiscal adjustments may result from the combined actions of several political actors in more decentralized systems operating under a cooperative institutional framework. Thus, we hypothesize here that the multi-layered fiscal structure, which characterizes most OECD countries, needs to be taken into account when assessing the durations of fiscal consolidations.

Our paper has analyzed the impact of fiscal decentralization on the durations of budgetary consolidation episodes in 17 OECD countries between 1978 and 2009. We find that: (1) consolidation episodes are longer in more decentralized countries, but only if subnational governments have little real autonomy over their budgets; and (2) transfers from central government are cut during consolidation periods, and this effect is more pronounced if sub-national authorities have little legal power to influence central government decisions. Thus, the local governments that are at greatest risk from fiscal retrenchment episodes seem to be those that have a considerable number of spending tasks and responsibilities, but which are not accompanied by sufficient legal power.

Although we have not undertaken a formal welfare analysis, it seems that it may well be desirable for countries to implement decentralization reforms to mitigate the negative effects of fiscal consolidation. Gradual consolidation packages may allow the private sector to adjust more smoothly to government spending cuts without suffering any negative disruptions (see Cogan et al. 2013). Moreover, "a steady pace of adjustment" is, in general, less harmful for the recovery than a frontloading approach (Blanchard and Cottarelli 2010) and a sustained improvement in government fiscal balances is likely to crowd-in private domestic investment and net foreign assets in the long run (Anderson et al. 2014). In short, institutional settings that favor consolidation processes of longer duration are to be preferred. From this perspective, our results contribute to identifying a "new" advantage of fiscal decentralization. Hence, structural reforms in this direction coupled with fiscal consolidation episodes might offset the negative near-term implications of an austerity policy linked to fiscal adjustments. 
The second piece of evidence revealed by our study concerns the implications our results have for the political economy. The fact that central governments reduce their transfers to lower tiers during fiscal adjustment processes may reveal a (possibly shortsighted) strategy of central governments to shift the adjustment burden onto lower government levels ${ }^{16}$ in order to appear virtuous in the eyes of both international markets and supranational institutions. This behavior runs contrary to the recommendations of the IMF (2013), which suggests that the best way to achieve credibility is to adopt medium-term fiscal plans with a visible anchor (e.g., either an average pace of adjustment or a fiscal target to be achieved within a certain period) combined with structural and institutional reforms, possibly involving different tiers of government.

Moreover, the central governments' behavior of cutting their transfers to sub-national units during consolidation episodes may extend these episodes and lead to the loss of political consensus at the regional level, which, in turn, is likely to be reflected in the results obtained at national representative elections. To ensure the success of adjustment strategies, the IMF (2013), in fact, recommends a different approach based on the coordination of financial decision-making across different government tiers. The difficulties in implementing this coordination strategy may, however, be one of the reasons why more decentralized countries manage to achieve, on average, smaller improvements in the budget balance/GDP ratio than those recorded by their less decentralized counterparts (as we document in the last section of our analysis).

Furthermore, the distributional effects of such policies across government levels have to be given due consideration. All in all, given that budget consolidation measures normally are unpopular, the duration of a consolidation episode also is relevant in light of the political support governments require in order to implement such measures. In this regard, our findings suggest that the sub-national debt-to-GDP ratio increases when consolidation packages are implemented at the country level. This shift in the burden onto local public finances seems to be mitigated, however, by the real authority enjoyed by the sub-national government and, in particular, on its ability to participate and share in the central government's policy-making and objectives, their implementation, and, ultimately, their success.

Acknowledgments The authors would like to thank the participants in the OECD Fiscal Federalism Network Workshop in Paris (November 2014), the 71st Annual Congress of the International Institute of Public Finance in Dublin (August 2015) and the 56th Conference of the Italian Economic Association in Naples (October 2015) for useful comments on previous versions of this paper. Special thanks are due to Giuseppe Di Liddo, Diego Martínez Lopez, Jaroslaw Kantorowicz, Antonio Jesús Sanchez Fuentes, Alberto Zazzaro, Bodhisattva Sengupta, the Editor and two anonymous referees for their insightful suggestions. This research has received funding from projects ECO2012-37131 and ECO2013-41310 (Ministerio de Economía y Competitividad), and 2014SGR-420 (Generalitat de Catalunya). The usual disclaimer applies.

Open Access This article is distributed under the terms of the Creative Commons Attribution 4.0 International License (http://creativecommons.org/licenses/by/4.0/), which permits unrestricted use, distribution, and reproduction in any medium, provided you give appropriate credit to the original author(s) and the source, provide a link to the Creative Commons license, and indicate if changes were made.

\footnotetext{
16 Actually, this burden-shifting may also be partly attributable to the fact that while many national governments suspended or abandoned national fiscal rules following the recent global financial crisis, rules concerning sub-national deficits and debts often remained in force.
} 


\section{References}

Adam, C., \& Bevan, D. (2003). Staying the course: Maintaining fiscal control in developing countries. In S. M. Collins \& D. Rodrik (Eds.), Brookings trade forum (pp. 167-227). Washington: Brookings Institution Press.

Afonso, A., Nickel, C., \& Rother, P. C. (2006). Fiscal consolidations in the Central and Eastern European countries. Review of World Economics, 142(2), 402-421.

Agnello, L., Castro, V., \& Sousa, R. M. (2013). What determines the duration of a fiscal consolidation program? Journal of International Money and Finance, 37, 113-134.

Alesina, A. F., \& Ardagna, S. (2010). Large changes in fiscal policy: Taxes versus spending. In J. R. Brown (Ed.), Tax policy and the economy (vol. 24, pp. 35-68). Chicago: The University of Chicago Press.

Alesina, A. F., \& Ardagna, S. (2012). The design of fiscal adjustments. National Bureau of Economic Research working paper no. w18423.

Alesina, A., \& Perotti, R. (1995). Fiscal expansions and adjustments in OECD countries. Economic Policy, $21,205-248$.

Anderson, D., Hunt, B., \& Snudden, S. (2014). Fiscal consolidation in the euro area: How much pain can structural reforms ease? Journal of Policy Modeling, 36(5), 785-799.

Ardagna, S. (2009). Financial markets' behavior around episodes of large changes in the fiscal stance. European Economic Review, 53(1), 37-55.

Armingeon, K., Weisstanner, D., Engler, S., Potolidis, P., \& Gerber, M. (2012). Comparative political data set I 1960-2010. Bern: University of Bern, Institute of Political Science.

Baldacci, E., Clements, B., Gupta, S., \& Mulas-Granados, C. (2006). The phasing of fiscal adjustments: What works in emerging market economies? Review of Development Economics, 10(4), 612-631.

Barrios, S., Langedijk, S., \& Pench, L. (2010). EU fiscal consolidation after the financial crisis: Lessons from past experiences. European Commission Economic Papers no. 418.

Bi, H., Leeper, E. M., \& Leith, C. (2013). Uncertain fiscal consolidations. The Economic Journal, 123(566), F31-F63.

Blanchard, O., \& Cottarelli, C. (2010). Ten commandments for fiscal adjustment in advanced economies. IMFdirect, June 24. http://blog-imfdirect.imf.org/2010/06/24/ten-commandments-for-fiscal-adjustment-inadvanced-economies/.

Blanchard, O., \& Leigh, D. (2013). Fiscal consolidation: At what speed? VoxEU.org, 3 May.

Blöchliger, H. (2013). Fiscal consolidation across government levels: Part 1. How much, what policies? OECD Economics Department Working Papers, No. 1070, OECD Publishing.

Blyth, M. (2013). Austerity: The history of a dangerous idea. Oxford: Oxford University Press.

Blöchliger, H., \& Vammalle, C. (2012). Reforming fiscal federalism and local government: beyond the zerosum game. Paris: OECD Publishing.

Briotti, M. G. (2004). Fiscal adjustment between 1991 and 2002: Stylised facts and policy implications. ECB Occasional Paper Series, No 9.

Cafiso, G., \& Cellini, R. (2014). Fiscal consolidations and public debt in Europe. International Tax and Public Finance, 21(4), 614-644.

Cogan, J. F., Taylor, J. B., Wieland, V., \& Wolters, M. H. (2013). Fiscal consolidation strategy. Journal of Economic Dynamics and Control, 37(2), 404-421.

Darby, J., Muscatelli, V. A., \& Roy, G. (2005). Fiscal consolidation and decentralisation: A tale of two tiers. Fiscal Studies, 26(2), 169-195.

Devries, P., Guajardo, J., Leigh, D., \& Pescatori, A. (2011). A new action-based dataset of fiscal consolidation. IMF Working Paper No. 11/128, Washington: International Monetary Fund.

Ebel, R., \& Yilmaz, S. (2003). On the measurement and impact of fiscal decentralization. In J. Alm \& J. Martinez-Vazquez (Eds.), Public finance in developing countries: Essays in the honour of Richard M. Bird (pp. 101-120). Northampton: Elgar.

Escolano, J., Eyraud, L., Moreno Badia, M., Sarnes, J., \& Tuladhar, A. (2012). Fiscal performance, institutional design and decentralization in European Union countries. IMF Working Paper no. 12/45, Washington: International Monetary Fund.

European Commission. (2007). European economy: Public finances in EMU. European Commission report. Eyraud, L., \& Moreno Badia, M. (2013). Too small to fail? Subnational spending pressures in Europe. IMF Working Paper no. 13/46, Washington: International Monetary Fund.

Foremny, D. (2014). Sub-national deficits in European countries: The impact of fiscal rules and tax autonomy. European Journal of Political Economy, 34, 86-110.

Foremny, D., Sacchi, A., \& Salotti, S. (2014). Fiscal adjustment, decentralization, and subnational autonomy. In: OECD fiscal federalism studies institutions of intergovernmental fiscal relations: Challenges ahead, OECD Publishing, chapter no. 4. 
Foremny, D., \& von Hagen, J. (2012). Fiscal federalism in times of crisis: Sharing the cost of adjustment. In: IEB World Report on Fiscal Federalism.

Foremny, D., \& von Hagen, J. (2013). Fiscal federalism in times of crisis, CEPR Discussion Paper No. DP9154.

Grüner, H. P. (2013). The political economy of structural reform and fiscal consolidation revisited. Economic Papers No. 487, DG ECFIN, European Commission.

Gupta, S., Baldacci, E., Clements, B., \& Tiongson, E. R. (2005). What sustains fiscal consolidations in emerging market countries? International Journal of Finance \& Economics, 10(4), 307-321.

Gupta, S., Clements, B., Baldacci, E., \& Mulas-Granados, C. (2004). The persistence of fiscal adjustments in developing countries. Applied Economics Letters, 11(4), 209-212.

Heylen, F., \& Everaert, G. (2000). Success and failure of fiscal consolidation in the OECD: A multivariate analysis. Public Choice, 105(1-2), 103-124.

Hooghe, L., Marks, G., \& Schakel, A. H. (2010). The rise of regional authority: A comparative study of 42 democracies. London: Routledge.

Illera, R. M., \& Mulas-Granados, C. (2008). What makes fiscal consolidations last? A survival analysis of budget cuts in Europe (1960-2004). Public Choice, 134(3-4), 147-161.

IMF. (2013). Reassessing the role and modalities of fiscal policy in advanced economies. IMF Policy Paper, September. Washington: International Monetary Fund.

IMF. (2014). Budget institutions in G-20 countries: An update. IMF Policy Paper, April. Washington: International Monetary Fund.

Jonas, J. (2012). Great recession and fiscal squeeze at U.S. subnational government level. IMF Working Paper no. 12/184, Washington: International Monetary Fund.

Lodge, D., \& Rodriguez-Vives, M. (2013). How long can austerity persist? The factors that sustain fiscal consolidations. European Journal of Government and Economics, 2(1), 5-24.

Mauro, P. (2011). Chipping away at the public debt: Sources of failure and keys to success in fiscal adjustment. Hoboken, NJ: Wiley.

Mauro, P., \& Villafuerte, M. (2013). Past fiscal adjustments: Lessons from failures and successes. IMF Economic Review, 61(2), 379-404.

Mauro, P., Romeu, R., Binder, A., \& Zaman, A. (2013). A modern history of fiscal prudence and profligacy. IMF Working Paper 13/5 (Washington: International Monetary Fund).

Molnar, M. (2012). Fiscal consolidation: Part 5. What factors determine the success of consolidation efforts? Technical report, OECD Publishing.

Nannicini, T., Grembi, V., \& Troiano, U. (2016). Do fiscal rules matter? American Economic Journal: Applied Economics, 8, 1-30.

Neck, R., \& Sturm, J. E. (2008). Sustainability of public debt. Cambridge: MIT Press.

Neyapti, B. (2010). Fiscal decentralization and deficits: International evidence. European Journal of Political Economy, 26(2), 155-166.

Neyapti, B. (2013). Fiscal decentralization, fiscal rules and fiscal discipline. Economics Letters, 121, $528-532$.

Ostry, J. D., Loungani, P., \& Furceri, D. (2016). Neoliberalism: Oversold. Finance \& Development, 53(2), $38-41$.

Perotti, R. (2012). The "austerity myth": Gain without pain? In Fiscal policy after the financial crisis (pp. 307-354). Chicago: University of Chicago Press.

Price, R. W. R. (2010). The political economy of fiscal consolidation. OECD Economics Department Working Paper no. 776.

Reuter, W. H. (2015). National numerical fiscal rules: Not complied with, but still effective? European Journal of Political Economy, 39, 67-81.

Rodríguez-Pose, A., \& Ezcurra, R. (2011). Is fiscal decentralization harmful for economic growth? Evidence from the OECD countries. Journal of Economic Geography, 11, 619-643.

Schaltegger, C. A., \& Feld, L. P. (2009). Are fiscal adjustments less successful in decentralized governments? European Journal of Political Economy, 25(1), 115-123.

Stegarescu, D. (2005). Public sector decentralisation: Measurement concepts and recent international trends. Fiscal Studies, 26(3), 301-333.

Thornton, J., \& Adedeji, O. S. (2010). Fiscal decentralization and fiscal consolidations in emerging market economies. Applied Economics Letters, 17(11), 1043-1047.

Tsibouris, G. C., Horton, M. A., Flanagan, M. J., \& Maliszewski, M. S. (2006). Experience with large fiscal adjustments. IMF Occasional Paper no. 246, Washington: International Monetary Fund.

Vammalle, C., \& Hulbert, C. (2013). Sub-national finances and fiscal consolidation: Walking on thin ice. OECD Regional Development Working Paper no. 02, OECD Publishing. 
Von Hagen, J., Hughes Hallett, A., \& Strauch, R. (2002). Budgetary consolidations in Europe: Quality, economic conditions and persistence. Journal of the Japanese and International Economies, 16(4), 512-535.

Von Hagen, J., \& Strauch, R. R. (2001). Fiscal consolidations: Quality, economic conditions, and success. Public Choice, 109(3-4), 327-346. 